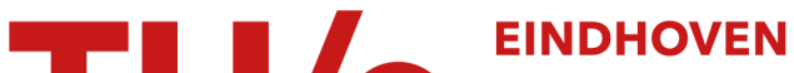 \\ UNIVERSITY OF \\ TECHNOLOGY
}

\section{Investigations of advanced folded reflectarray antennas}

Citation for published version (APA):

Dieter, S., Li, J., Keyrouz, S., \& Menzel, W. (2010). Investigations of advanced folded reflectarray antennas. In Proceedings of the 2010 International Conference on Electromagnetics in Advanced Applications (ICEAA), 2024 September 2010, Sydney, Australia (pp. 89-92). Institute of Electrical and Electronics Engineers. https://doi.org/10.1109//CEAA.2010.5651732

DOI:

10.1109/ICEAA.2010.5651732

Document status and date:

Published: 01/01/2010

\section{Document Version:}

Publisher's PDF, also known as Version of Record (includes final page, issue and volume numbers)

\section{Please check the document version of this publication:}

- A submitted manuscript is the version of the article upon submission and before peer-review. There can be important differences between the submitted version and the official published version of record. People interested in the research are advised to contact the author for the final version of the publication, or visit the $\mathrm{DOI}$ to the publisher's website.

- The final author version and the galley proof are versions of the publication after peer review.

- The final published version features the final layout of the paper including the volume, issue and page numbers.

Link to publication

\section{General rights}

Copyright and moral rights for the publications made accessible in the public portal are retained by the authors and/or other copyright owners and it is a condition of accessing publications that users recognise and abide by the legal requirements associated with these rights.

- Users may download and print one copy of any publication from the public portal for the purpose of private study or research.

- You may not further distribute the material or use it for any profit-making activity or commercial gain

- You may freely distribute the URL identifying the publication in the public portal.

If the publication is distributed under the terms of Article $25 \mathrm{fa}$ of the Dutch Copyright Act, indicated by the "Taverne" license above, please follow below link for the End User Agreement:

www.tue.nl/taverne

Take down policy

If you believe that this document breaches copyright please contact us at:

openaccess@tue.nl

providing details and we will investigate your claim. 


\title{
Investigations of Advanced Folded Reflectarray Antennas
}

\author{
$\begin{array}{llll}\text { S. Dieter } & \text { J. Li } & \text { S. Keyrouz J. Ren } & \text { W. } \text { Menzel }^{2}\end{array}$
}

\begin{abstract}
This paper reports on recent research on folded reflectarray antennas done at the University of UIm. The first area of work deals with the investigations of reflector elements with improved phase angle range and the influence of different effects on bandwidth and antenna gain including cell type, size, or substrate layer structure. A second area of work is the precise characterization of reflector elements, both with respect to the phase angle as well as the polarization twisting. Two methods have been developed for such characterization at frequencies around $77 \mathrm{GHz}$, one based on a quasi-optical Gaussian beam setup, another one based on near-field probing.
\end{abstract}

\section{INTRODUCTION}

Printed planar reflectarrays [1-4] have gained increasing interest due to their low weight, design flexibility, or ease of fabrication. A more compact version of such antennas is provided by folded reflectarray antennas [3-4] which have already been implemented into an automotive radar. The cross section of a folded reflectarray antenna is shown in Fig. 1. This antenna consists of a circular feed, a polarizing grid printed on a dielectric substrate, and the specific reflectarray substrate with printed metal elements like rectangular patch elements, which, simply by their geometry, both can adjust the overall phase angle and twist the polarization of the incoming wave by $90^{\circ}$ using a $180^{\circ}$ phase shift between the two polarizations of the reflected wave. This dual function requires an independent adjustment of the reflection phase angles for both polarizations.

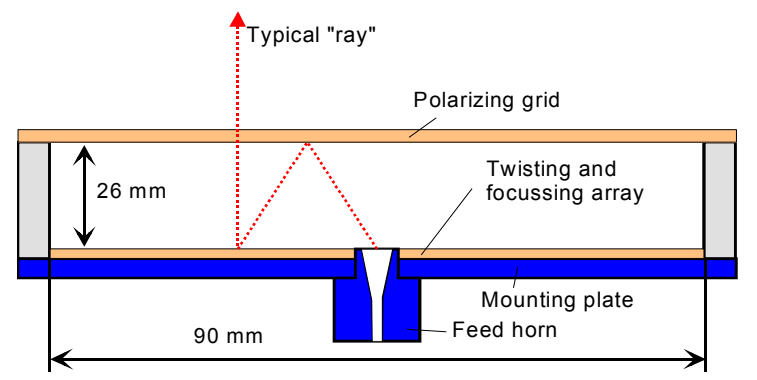

Fig. 1: Principle of a folded reflectarray antenna.

\section{NOVEL REFLECTOR ELEMENTS}

A disadvantage of simple rectangular patches for single-layer reflectarrays is a reduced phase angle range of only $300^{\circ} \ldots 320^{\circ}$. This problem may be overcome by dual or triple layer reflectarrays, e.g. [4].
The underlying principle are coupled resonances, thus doubling or tripling the available range of phase angles. For some application, however, like in automotive radars, such multilayer substrates with their increased fabrication effort and cost are not acceptable.

A solution of this problem could be the realization of coupled resonators on a single layer. In addition, in this case, a thicker substrate can be used resulting in a flatter phase curve. Recently, some modified structures have been proposed for an increased phase angle range for single polarization, e.g. [5-11], based on multiple elements, partly combined with slots. Losses now occur at both resonances, although losses may be lower. The two resonances should be close together to achieve a flat phase curve. For folded reflectarrays, phase adjustment is necessary independently for both polarizations requiring some degree of double symmetry.

Two of such elementary structures with dual resonances are shown in Fig. 2 top. The first one (three fingers) exhibits a double resonance based on different lengths of narrow strips, the second one (crossed elements) has different resonance frequencies based on two adjacent elements. To provide $180^{\circ}$ phase shift and maintaining double symmetry, four substructures each are combined to one unit cell. The phase angle behavior of the left structure is given in Fig. 2 bottom; the right structure shows a similar performance; both with a phase angle range of more than $500^{\circ}$. A reference antenna with simple rectangular elements (on a $0.254 \mathrm{~mm}$ thick substrate) and one antenna each with the cells as shown in Fig. 2 were designed, fabricated, and tested. All three antennas result in similar radiation diagrams as shown in Fig. 3 for the reference antenna, where the two modified antennas exhibit slightly higher beamwidths.

Antenna losses also were tackled with another approach. With the usual PTFE substrates, the interface between substrate and metallization is roughened to ensure a good bonding strength of the metal, leading to increased losses from surface currents at the rough interface. In a new antenna approach, the metallization has been etched on a thin substrate $\left(\mathrm{h}=0.127 \mathrm{~mm}, \varepsilon_{\mathrm{r}}=2.2\right.$ ), this was then bonded face down on the main substrate. In this way, the main surface current is flowing on the much smoother top side of the metallization, reducing current losses [12].

\footnotetext{
${ }^{1}$ Institute of Microwave Techniques, University of Ulm, PO Box, D-89069 Ulm, Germany, e-mail: sabine.dieter@uni-ulm.de, tel.: +49 731 5026377, fax: +49 7315026359.

${ }^{2}$ Institute of Microwave Techniques, University of Ulm, PO Box, D-89069 Ulm, Germany, e-mail: wolfgang.menzel@uni-ulm.de, tel.: +49 731 5026350, fax: +49 7315026359.
} 
Two antennas based on this approach have been realized, one with interleaved rhombs as elements, one based on the structure as shown in Fig. 2, top left. Fig. 4 compares the gain behavior of all realized antennas.

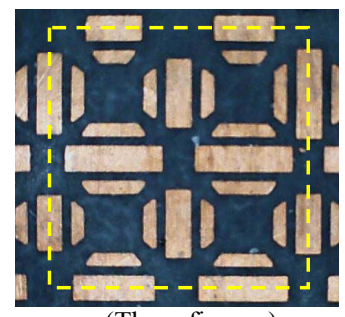

(Three fingers)

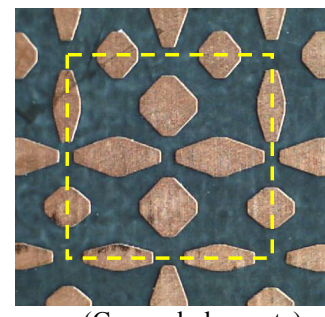

(Crossed elements)

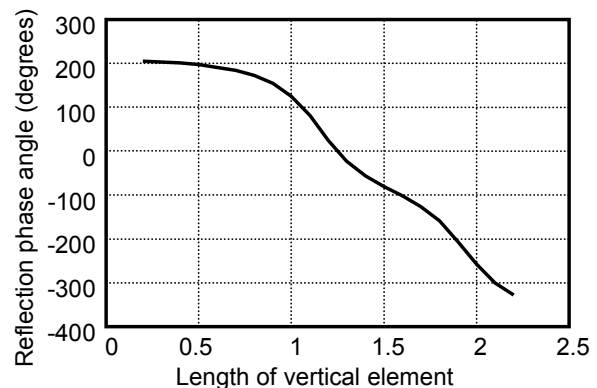

Fig. 2: Cell structures for two modified twist reflector (top) and reflection phase angle of the left structure on top for vertical polarization as a function of the vertical length $\mathrm{L}_{1 \text { vert }}$ of the sub-structure. $\left(\mathrm{L}_{1 \text { hor }}=1.2 \mathrm{~mm}\right.$, substr. thickness $\left.0.5 \mathrm{~mm}, \varepsilon_{\mathrm{r}}=2.22, \mathrm{f}=76.5 \mathrm{GHz}\right)$.

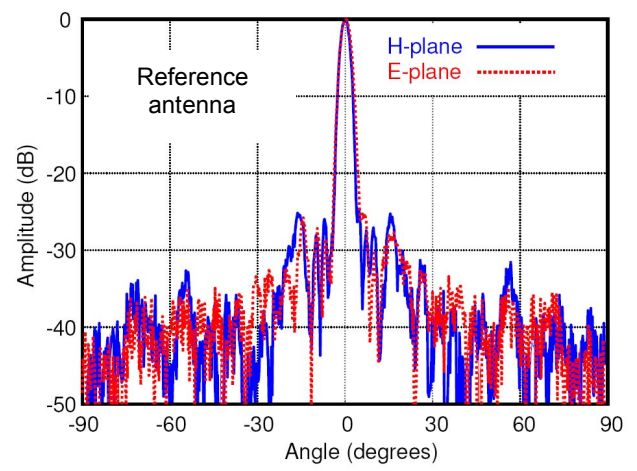

Fig. 3: E-plane and H-plane radiation diagrams of the reference antenna at $76.5 \mathrm{GHz}$.

The reference antenna and that with the covered rhombs show the best gain with a maximum of about $33 \mathrm{~dB}$ and a $3 \mathrm{~dB}$ bandwidth of $10 \ldots 11 \mathrm{GHz}$. The element cell size of the antennas with the three finger patches and the crossed patches are quite large with phase angle errors, especially towards the antenna edges (slant incidence of the waves), resulting in wider beamwidths and reduced gain. An improvement for the covered three finger patch antenna can be observed; this one has smaller element cells having dielectric material on both sides of the metallization and the improved metal losses.

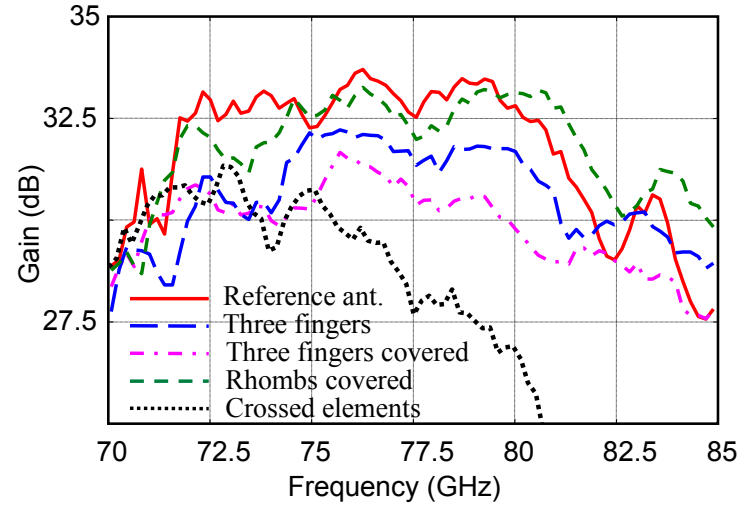

Fig. 4: Gain of reference and four test antennas.

\section{CHARACTERIZATION METHODS}

Besides simulation results of prototype unit cells, it is important to investigate the reflection behavior of reflectarray structures experimentally including deviations due to fabrication tolerances. In this chapter, two characterization methods for unit cells with a polarization twist are introduced, investigating their absolute reflection phase angles and their ability of polarization twisting as well.

The first characterization method is based on a quasi-optical Gaussian beam setup with polarization separation, the second one is based on near-field probing using special, very compact probes developed for this application. First investigations have been made around $35 \mathrm{GHz}$ ([13], [14]), now measurements are possible also in the $77 \mathrm{GHz}$ frequency range.

Fig. 5 shows a periodic array of patches designed by use of [15] as a test structure for the characterization measurements at $77 \mathrm{GHz}$. The Rogers substrate RT5880 $\left(\varepsilon_{\mathrm{r}}=2.2\right)$ with printed patches is backsidemetalized; substrate thickness is $0.5 \mathrm{~mm}$. Unit cell size is $2.14 \mathrm{~mm} \times 2.14 \mathrm{~mm}$. The specific dimensions of the chosen patch size $(0.735 \mathrm{~mm} \times 1.56 \mathrm{~mm})$ lead to a reflection phase angle difference of $180^{\circ}$ between the two field components $\mathrm{E}_{\mathrm{x}}$ and $\mathrm{E}_{\mathrm{y}}$. An incident electric field with polarization $\mathrm{E}_{\mathrm{in}}$, tilted by $45^{\circ}$ against the patches' axes, results in a polarization twisting of the reflected wave $\mathrm{E}_{\mathrm{refl}}$ by $90^{\circ}$.

\subsection{Quasi-optical measurements}

According to Fig. 5, a decomposition of the reflected components into the two polarizations $\mathrm{E}_{\mathrm{x}}$ and $\mathrm{E}_{\mathrm{y}}$ helps to characterize their reflection phase angle difference and therefore to verify the polarization twisting. A quasi-optical Gaussian beam setup with polarization separation is shown in Fig. 6. The setup consists of three horn antennas h1 to h3, the device under test (DUT), and two square arrangements of lenses. Square I - with a diagonal dielectric sheet - is acting as a quasi-optical directional coupler for the incident 
signal and the signal reflected from the DUT. The horn antenna h1 transmits under an angle of $45^{\circ}$, therefore including both field components $\mathrm{E}_{\mathrm{x}}$ and $\mathrm{E}_{\mathrm{y}}$. Part of the wave is reflected at the dielectric sheet in square region I and guided to the DUT, which is located at the waist of the Gaussian beam. The reflected wave passes the dielectric sheet and enters region II. There, a horizontally orientated grid separates the two polarization components $\mathrm{E}_{\mathrm{y}}$ and $\mathrm{E}_{\mathrm{x}}$, which then are detected via horn antennas $\mathrm{h} 2$ and $\mathrm{h} 3$. The grid is realized on a Rogers RT5880 substrate $\left(\varepsilon_{\mathrm{r}}=2.2\right)$ with a thickness of $1.143 \mathrm{~mm}$, the polarization separation is better than $20 \mathrm{~dB}$ in the considered frequency region from $76 \mathrm{GHz}$ to $79 \mathrm{GHz},[15]$.

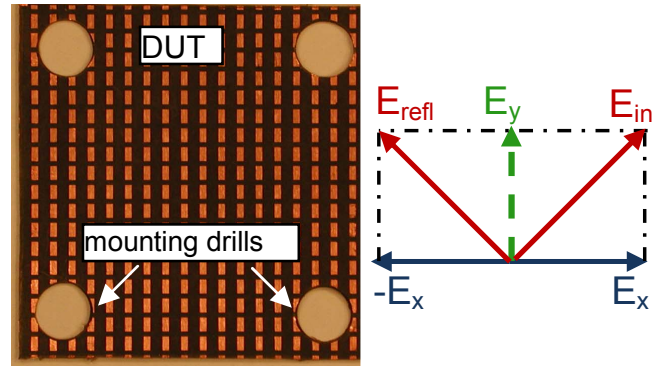

Figure 5: Test structure with polarization twist.

The reflection phase angles of the separated field components $\mathrm{E}_{\mathrm{x}}$ and $\mathrm{E}_{\mathrm{y}}$ using this quasi-optical setup are shown in Fig. 7. Their phase angle difference is consistent with the simulated results from [15]. The reason for a slight deviation between measurement and simulation can be explained by a low ripple over frequency for the measurement of $E_{y}$ due to a standing wave in that path. This effect was reduced by adding some absorbing material.

\subsection{Near-field characterization}

Another experimental method is the examination of the test array (DUT) in a near-field measurement setup as shown in Fig. 8. The patch array is illuminated by an open waveguide (WG), and the reflected field is detected in the near-field using a probe with high spatial resolution. For this purpose, a special probe has been developed for $77 \mathrm{GHz}$. Its design is based on substrate-integrated waveguide with a high- $\varepsilon_{\mathrm{r}}$ substrate, metalized on top and bottom; the sidewalls are realized with rows of vias.

The test array (DUT) includes patches with the same dimensions as those investigated in the quasi-optical setup. This time, patches are printed on the array in regions with both orientations, as it can be seen in Fig. 8.

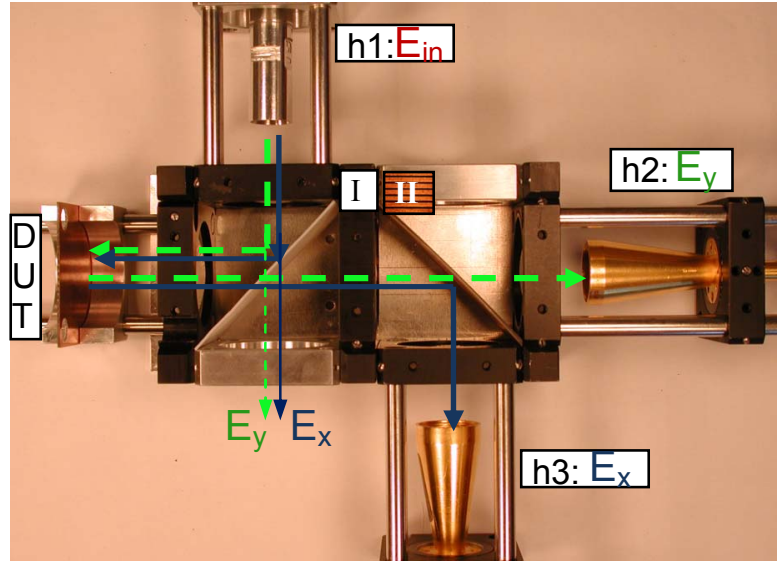

Figure 6: Quasi-optical measurement setup.

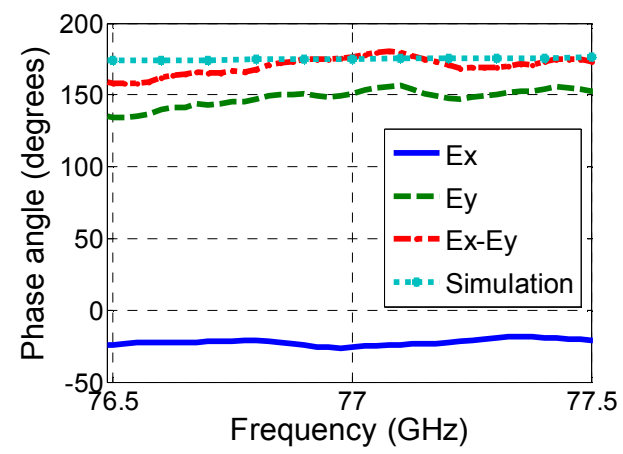

Figure 7: Measured phase angles with the quasi-optical measurement setup.
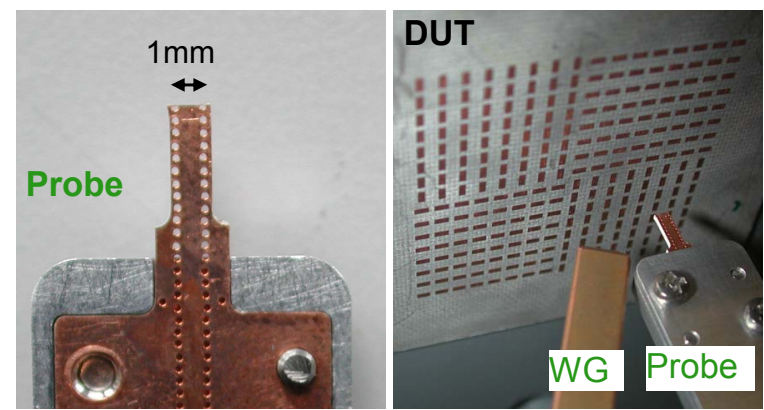

Figure 8: Probe and measurement setup.

As the polarization directions of both the illuminating waveguide and the probe are oriented in the same direction $\left(\mathrm{E}_{\mathrm{y}}\right)$, the other component $\left(\mathrm{E}_{\mathrm{x}}\right)$ can be measured in another array region with the patches rotated by $90^{\circ}$. Fig. 9 shows the phase angles of a near-field scan with this measurement setup, using a step width of $0.2 \mathrm{~mm}$. The measured phase angle difference of the patches with the two orientations is almost $180^{\circ}$. 


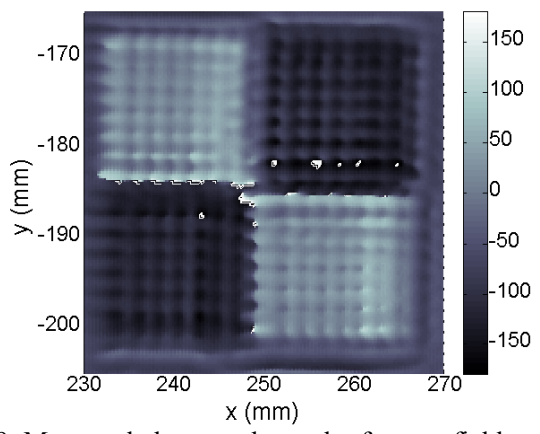

Figure 9: Measured phase angle result of a near-field measurement scan of the test array.

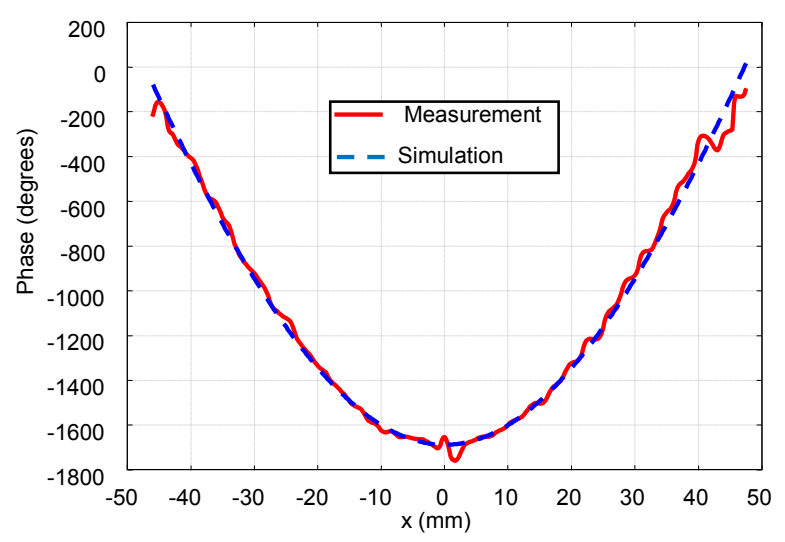

Figure 10: Measured reflection phase angle of a folded reflectarray antenna compared to ideal phase angle values.

Another test with the given setup is a radial scan at the center of a reflectarray antenna, see Fig. 10. In this case, the polarizations of feeding waveguide and probe were oriented orthogonal to each other. The measured (and unwrapped) curve of the absolute reflection phase angle and the theoretical results agree in an excellent way.

\section{CONCLUSION}

This paper reports on recent research on folded reflectarray antennas. Investigations of novel reflector elements have been shown, antenna designs and measurements based on these structures are presented. In the field of characterization of polarization twisting elements for reflectarray antennas, two measurement setups have been introduced and verified by measurement results: one is based on a quasi-optical Gaussian beam setup, the other one uses near-field measurements with high-resolution probes developed for this purpose.

\section{Acknowledgments}

Part of this work has been funded by the German Research Association (DFG) under the contract ME 1016/14-2.

\section{References}

[1] J. Huang, "Microstrip reflectarray," IEEE Antennas and Propagation Society International Symposium, 1991. AP-S 1991, pp. $612-615$.

[2] D. M. Pozar, S. D. Targonski, H. D. Syrigos, "Design of millimeter wave microstrip reflectarrays," IEEE Trans. on Antennas and Propagation, Vol. AP-45 (1997), pp. 287 - 296.

[3] W. Menzel, D. Pilz, and M. Al-Tikriti, "MM-Wave Folded Reflector Antennas with High Gain, Low Loss, and Low Profile," IEEE AP Magazine, June 2002, pp. 24 - 29.

[4] J. A. Zornoza , R. Leberer, M. Moraga, J. A. Encinar and W. Menzel, "A folded 3-layer printed reflectarray with shaped pattern for LMDs central station sectored antenna," IEEE Int. Symposium on Antennas and Propagation, Monterey, USA, July 2004, Vol. 1, pp. 5 - 8.

[5] M. R. Chaharmir, J. Shaker, M. Cuhaci, and A. Ittipiboon, "Broadband reflectarray antenna with double cross loops," Electronics Letters, vol. 42, no. 2, pp. 65-66, Jan. 19, 2006.

[6] M. R. Chaharmir, J. Shaker, M. Cuhaci, A. Ittipiboon, " $A$ Broadband Reflectarray Antenna with Double Square Rings as the Cell Elements," 1st European Conference on Antennas and Propagation (EuCAP), Nice, France, 2006.

[7] D. Cadoret, L. Marnat, R. Loison, R. Gillard, H. Legay, and B. Salome, "A dual linear polarized printed reflectarray using slot loaded patch elements," in Proc. Second European Conference on Antennas and Propagation EuCAP 2007, Nov. 11-16, 2007, pp. 1-5.

[8] K. H. Sayidmarie and M.E. Bialkowski, "Investigations into Unit Cells offering an increased Phase Range for Single Layer Printed Reflectarrays," Microwave and Optical Technology Letters, Vol. 50, No. 4, April 2008, 1028-1032.

[9] M. E. Bialkowski, A. M. Abbosh, and K. H. Sayidmarie, "Investigations into phasing characteristics of printed single and double cross elements for use in a single layer microstrip reflectarray," in Proc. IEEE Antennas and Propagation Society International Symposium AP-S 2008, Jul. 5-11, 2008, pp. 14.

[10] S. Dieter, C. Fischer, W. Menzel, "Single-Layer Unit Cell with Optimized Phase Angle Behavior," Third European Conference on Antennas and Propagation, 2009, Berlin.

[11] W. Menzel, J. Li, and S. Dieter, "Folded reflectarray antenna based on a single layer reflector with increased phase angle range," in Proc. 3rd European Conference on Antennas and Propagation EuCAP 2009, Mar. 23-27, 2009, pp. 2757-2760.

[12] G. Fischer, University of Erlangen, Germany, personal communication.

[13] S. Dieter, and W. Menzel, "High-Resolution Probes for Near-Field Measurements of Reflectarray Antennas", in IEEE Antennas and Wireless Propagation Letters, 2009, Vol. 8, pp. 157-160.

[14] S. Dieter, A. Moessinger, S. Mueller, W. Menzel, and R. Jakoby, "Characterization of Reconfigurable LCReflectarrays Using Near-Field Measurements ", in Proc. Of $4^{\text {th }}$ German Microwave Conference GEMIC, 2009, Mar. 1618 , pp.1-4.

[15] Ansoft Designer 5.0.2, ANSYS Inc., Canonsburg, PA, 2010. 